\title{
The benefit of one cannot replace the other: seagrass and mangrove ecosystems at Santa Fe, Bantayan Island
}

\author{
Ayana Rose R. Mendoza* (D), Jenny Marie R. Patalinghug and Joshua Ybañez Divinagracia
}

\begin{abstract}
Background: In the Philippines, the practice of planting mangroves over seagrass has been a practice done to promote coastline protection from damages done by storms. Despite the added protection to the coastline, the addition of an artificial ecosystem gradually inflicts damage to the ecosystem already established. In this study, seagrass communities that had no history of mangrove planting were compared with those that had mangrove planting. The percent substrate cover of seagrass in the sampling areas was determined, and the macroinvertebrates present in the sampling areas were also observed. The study was conducted based on reports of mangrove planting activity that disrupted seagrass functions on Santa Fe, Bantayan Island, Cebu. Transectquadrat method sampling was done to assess the chosen sites.

Results: Six species of seagrass was found on the site without mangrove planting which was barangay Ocoy (Cymodocea sp., Thalassia sp., Halodule sp., Enhalus sp., Halophila sp., and Syringodium sp.) and had a higher percent cover, while only four were found on the site with mangrove planting (barangay Marikaban). It was also found that barangay Marikaban had a lesser Shannon-Wiener and Simpson's index compared to barangay Ocoy. Jaccard's index of similarity between the two sites was low.
\end{abstract}

Conclusion: With the results of the assessment, we recommend proper monitoring of future mangrove planting activities and that these activities should not disrupt another ecosystem as all ecosystems are important.

Keywords: Seagrass, Mangrove planting, Diversity index

\section{Background}

Coastal seas, a part of the ever abundant marine ecosystem, have been utilized by humans as a source of livelihood such as transportation and fishery. Human activity has contributed to the deterioration of quality in seas all over the world (Park et al. 2015). A big part of the marine ecosystem that is found in coastal areas is the seagrass beds.

Seagrass beds have a role in maintaining the population of fish and invertebrate species that are of economic significance by providing a permanent habitat in some fish or a temporary nursery for the development of juveniles in other fish. The beds indirectly maintain fisheries by supplying organic matter that is

\footnotetext{
* Correspondence: yani.10696@gmail.com

Biology Department, University of San Carlos, Talamban Campus, Cebu City, Philippines
}

(c) The Author(s). 2019 Open Access This article is distributed under the terms of the Creative Commons Attribution 4.0 International License (http://creativecommons.org/licenses/by/4.0/), which permits unrestricted use, distribution, and reproduction in any medium, provided you give appropriate credit to the original author(s) and the source, provide a link to the Creative Commons license, and indicate if changes were made. The Creative Commons Public Domain Dedication waiver (http://creativecommons.org/publicdomain/zero/1.0/) applies to the data made available in this article, unless otherwise stated.

incorporated into the coastal nutrient cycles which supports secondary production (Jackson et al. 2001). Another component of coastal ecosystems is the mangroves. Mangroves act as the buffer between land and sea, and they are not only utilized as breeding grounds and habitats for marine life but they are also used as source of provisions such as firewood, timber, and charcoal (Brander et al. 2012). In the Philippines, many seagrass beds are being planted with mangroves to protect coastlines from the tropical storms and other water-related calamities. According to reports by Cebu Chamber of Commerce and Industry-Bantayan Island Chapter (CCCI-BC) of the Department of Environment and Natural Resources (DENR), the implementation of seagrass rehabilitation in Bantayan Island, Cebu, is a must, due to the obstruction done by mangrove planting on the seagrass beds which affected the livelihood of fishermen who rely on shells 
and fish that live in the seagrass beds (Mangubat 2012). The country has the tendency to plant monospecific Rhizophora mangrove forests in areas that are not the natural habitat of the species. This practice leads to stunted growth and high mortality of the planted mangrove seedlings (Samson and Rollon 2008).

Some barangays in Santa Fe, Bantayan Island, depict these practices of planting mangrove propagules on seagrass beds. A "barangay" by definition is the smallest territorial and political subunit in the Philippine government which consists of 50 to 100 families headed by the barangay captain. Before mangrove planting activities occurred, Barangay Marikaban of Santa Fe, Bantayan Island, naturally had a scanty number of mangrove species growing in their beaches as reported by the locals during site visit. In the year 2013, Typhoon Haiyan devastated Bantayan Island, and strong storm surges destroyed the mangroves. Due to this, mangrove planting activities on the island were initiated. In the process, members of the Sea Fisherman's Association in Barangay Marikaban planted Rhizophora species on seagrass beds. However, not all barangays participated in this practice. One of these is Barangay Ocoy which is situated near the port of the same island. There was no activity of mangrove planting in the area as observed.

This study aims to compare seagrass communities that had no history of mangrove planting with those that had mangrove planting with the following specific objectives: to determine the percent cover of seagrass in the sampling areas and to observe the macroinvertebrates present in the sampling areas. We limit our study to percent cover since we only sought to assess if there is a difference with those seagrass beds that had reports (Mangubat 2012) of mangrove planting and those without. This study will enlighten readers of the importance in conserving the natural seagrass ecosystem despite the notion that mangrove ecosystems are more beneficial.

\section{Materials and methods}

The site chosen for this study was Santa Fe, Bantayan Island of Northern Cebu. The island is known to have abundant seagrass beds as mentioned by the Bureau of Fisheries and Aquatic Resources Region-VII (2009). Since there has already been reports (Mangubat 2012) of a community planting mangrove on the seagrass bed in some areas, this place was chosen. Biodiversity indices and physico-chemical parameters were measured for comparison.

\section{Study site}

The study was conducted in two barangays of Santa Fe in Bantayan Island. Site selection was based on mangrove planting activity in the area as learned from reports (Mangubat 2012; Codilla 2015a, b; Quintas 2015). Barangay Ocoy had no reports of mangrove planting in the area while barangay Marikaban had reports of mangrove planting. Figure 1 is a map showing the different sampling areas while Fig. 2 shows photographs taken in areas with mangrove and without mangrove.

\section{Seagrass assessment}

Transect-quadrat method was utilized for sampling. Two 100- $\mathrm{m}$ transects per barangay were positioned from where the seagrass patches started, going seaward, and were $100 \mathrm{~m}$ apart. A $0.5 \times 0.5$ - $\mathrm{m}$ quadrat was established every $10 \mathrm{~m}$ of each transect line (10 quadrats). These two transects were established on both barangays. Species identification of seagrass was done with the aid of field guides (McKenzie et al, 2003). Identification was only up to genus level. Percent seagrass cover on the substrate and macroinvertebrates that were inside the quadrats were taken into account. Investigation of both seagrass and macroinvertebrates was done on foot since the sampling was done during low tide.

\section{Physico-chemical parameters}

Physico-chemical parameters such as dissolved oxygen (DO), temperature, $\mathrm{pH}$, relative humidity $(\mathrm{RH})$, and salinity were assessed at each quadrat (3 trials). Different probes were used in the collection of physico-chemical data. The values for dissolved oxygen (DO) were acquired with the use of DO meter-thermo scientific model (Thermo Orion star A123) by dipping the tip of the probe 3 in. below the surface of the water. A Psychrometer-Bacharach model (12-7043 RED SPIRIT ${ }^{\circ}$ C) was then used in the gathering of data for relative humidity by comparing the temperature from the dry bulb and the wet bulb to the given scale on the meter after it was spun for $5 \mathrm{~min}$ while exposed to the atmosphere. The $\mathrm{pH}$ values were then acquired with the use of $\mathrm{pH}$ meter-thermo scientific model (Thermo Orion Star A121) by dipping the tip of the probe $3 \mathrm{in}$. below the surface of the water. A standard glass thermometer was also used to acquire data for the water temperature and air temperature by touching the tip of the glass thermometer on the surface of the water and by exposing the thermometer to the atmosphere respectively. Lastly, an ATAGO model (ATAGO S/Mill-E) was used for the collect of data for salinity by placing a drop of saltwater on the sample plate.

\section{Data analysis}

Measures of biodiversity for the macroinvertebrates, species richness, dominance, Simpson's index, Shannon-Wiener, and evenness were calculated. Jaccard's similarity index based on the absence and presence of macroinvertebrates 


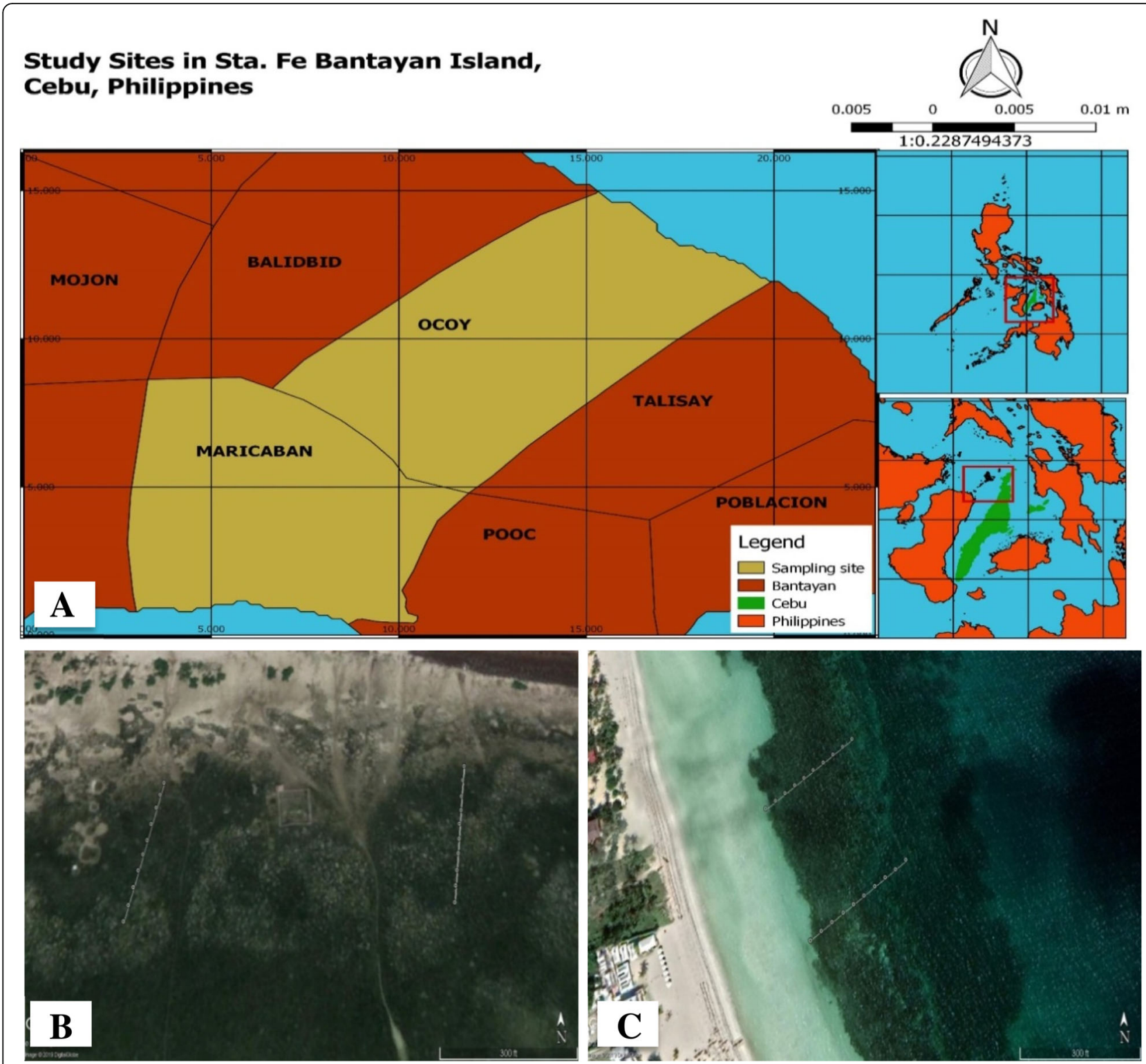

Fig. 1 Map of the two study sites in Bantayan, Cebu (a) which shows the two transect lines with their corresponding points for each quadrat established in areas with mangrove (b) and without mangrove (c)

and seagrass species was used to determine similarity of seagrass communities between barangays Ocoy and Marikaban. Macroinvertebrates were considered as they are bioindicators (Roozbahani et al. 2010). All calculations were done by using Paleontological Statistic Software (PAST) version 3.20. The software was used to determine measures of macroinvertebrate diversity, as these animals are associated with seagrass ecosystems and some are sources of livelihood for locals (gleaning). Statistical analysis was done using Microsoft Excel 2010. An unpaired $t$ test was conducted to determine significant differences of physico-chemical parameters, biodiversity measures, and seagrass substrate cover between the two sites.

\section{Results}

\section{Seagrass composition and substrate cover}

We went to these barangays, conducted assessments, and interacted with the locals. Table 1 displays the seagrass species that were present in the barangays. Barangay Ocoy had six species of seagrass while Barangay Marikaban had four. This is consistent with the Participatory Coastal Resource Assessment (PCRA) of Santa $\mathrm{Fe}, \mathrm{Cebu}$, report done by $\mathrm{BFAR}^{7}$. Their assessment was conducted in the year 2009. In their report, Barangay Marikaban also only has four species as it lacked Halophila sp. and Syringodium sp. while Ocoy had all six. As the study was conducted, it was observed that the 


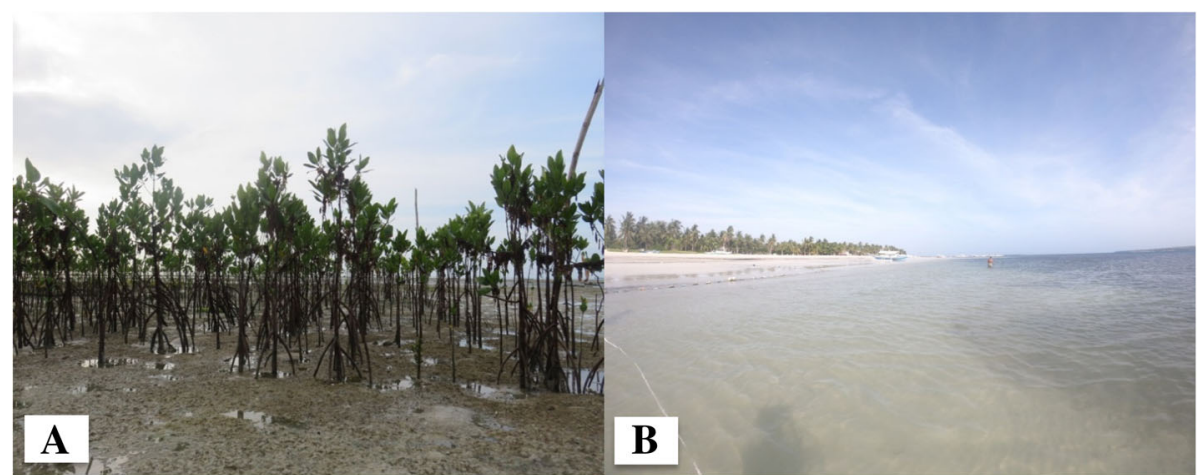

Fig. 2 Mangrove planting on seagrass beds (a) and site with no mangroves on seagrass beds (b)

seagrass composition in the quadrats that were nearing the mangrove seedlings was lesser. Species of Cymodocea were the ones that could grow with mangroves. Mean percent substrate cover of the seagrasses in both areas is presented in Fig. 3.

The mean percent substrate cover of the seagrasses in Barangay Marikaban was a bit lower (48.67\%) compared to Barangay Ocoy that had a mean percent substrate cover of $50.78 \%$. The lower seagrass cover experienced in Marikaban was most likely attributed to the mangrove seedlings that were planted over them. It was observed that the mangrove seedlings and seagrasses were competing for space in the area. The seagrasses were also patchier in their beach. The seagrass cover of Barangay Ocoy was higher, but their difference was not statistically significant $(p=0.84)$. This could be because some quadrats were already gradating towards the coral ecosystem. These quadrats were ecotones between the natural seagrass and coral ecosystems, so a mix of their growth was observed.

\section{Macroinvertebrate diversity}

Table 2 presents the measures of biodiversity that were generated for macroinvertebrates.

Table 1 Distribution of seagrass species in the study areas planted with mangroves (Barangay Marikaban) and without mangrove plantation (Barangay Ocoy)

\begin{tabular}{lll}
\hline Species & With mangrove & Without mangrove \\
\hline Cymodocea $s p$. & + & + \\
Thalassia sp. & + & + \\
Halodule $s p$. & + & + \\
Enhalus $s p$. & + & + \\
Halophila $s p$. & - & + \\
Syringodium $s p$. & - & + \\
Total number of species & 4 & 6 \\
\hline
\end{tabular}

"+" indicates present and " - " indicates absent
As presented, the diversity of macroinvertebrate fauna associated in the seagrasses of Barangay Marikaban was a bit lower compared to that in Ocoy. The difference between the scores in the biodiversity indices of the two areas was however not statistically significant. Marikaban had higher species richness but lower scores in diversity indices $\left(H\right.$ and $D_{\mathrm{s}}$ ) because there were species that dominated the community. This is also evident by the dominance index $(D)$ of Marikaban being higher than in Ocoy. It was observed that hermit crabs were most abundant in Marikaban. Jaccard's coefficient of similarity $\left(S_{\mathrm{J}}\right)$ was calculated to see how similar the macroinvertebrate species of the two areas was. The $S_{\mathrm{J}}$ was about 0.14 ; this means that their similarity was very low.

\section{Physico-chemical parameters}

The different physico-chemical parameters of the seagrass ecosystems in the two barangays were measured to see if the presence of mangroves altered these environmental parameters. The measuring of these parameters was however done only during the seagrass assessment dates, so results would not be entirely conclusive. These results would provide a snapshot of the environmental conditions of the area. Figure 4 presents the different physico-chemical parameters that were measured in the two areas.

All the physico-chemical parameters measured between the two sites were different. Their difference was statistically significant (Fig. 4). The relative humidity in Barangay Marikaban was higher because it was raining during the time of assessment. This also explains why the salinity of Marikaban was lower. The waters of Marikaban, however, were warmer than that of Ocoy despite the rain. The $\mathrm{pH}$ of the two areas were both alkaline. Waters around the seagrass of Ocoy was more basic. The dissolved oxygen of Marikaban was higher than that of Ocoy. Years of monthly monitoring to see the effect of mangrove planting on the environmental parameters of the 


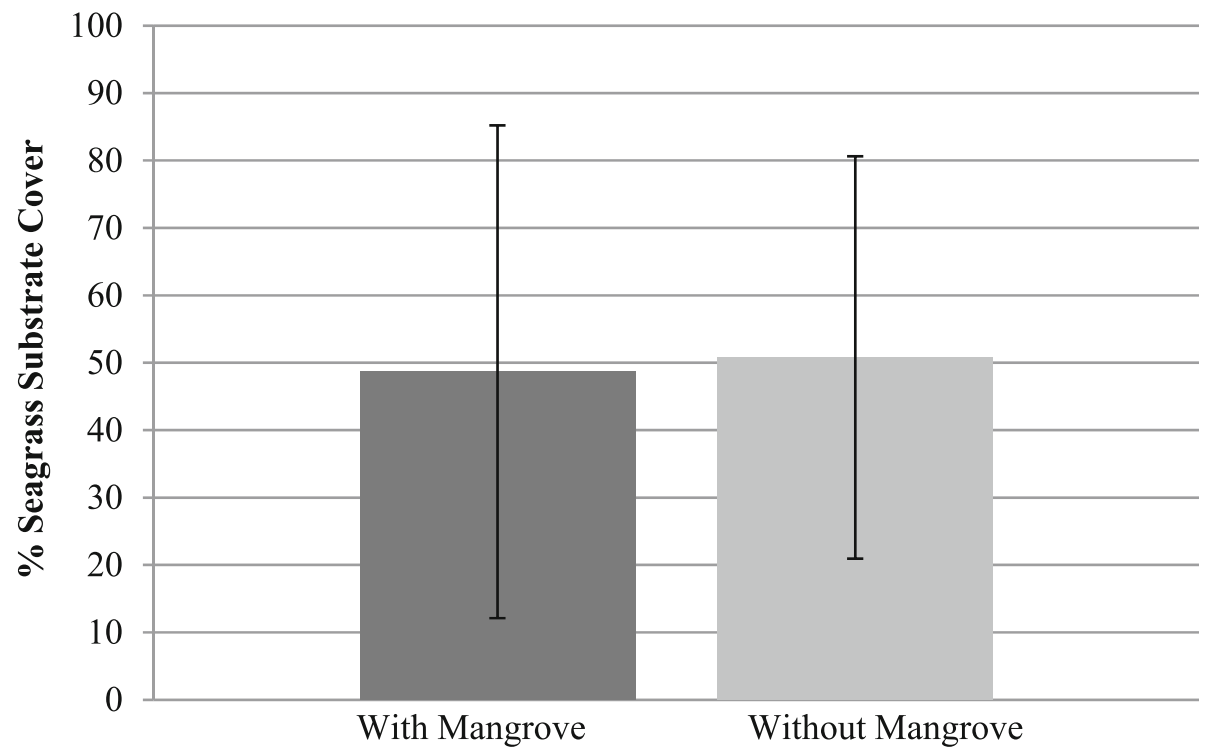

Fig. 3 Variation in mean percent seagrass substrate cover at sites planted with mangroves (Barangay Marikaban) and without mangrove plantation (Barangay Ocoy) having $p=0.84256$

seagrass ecosystem is recommended for better and conclusive insights.

\section{Discussion}

In the Philippines, mangrove planting has become an activity that the government encourages. The country has had a problem of mangrove forests being turned into aquaculture ponds, but since the 1930s and to the present, this problem has slowly been addressed through mangrove planting initiatives. The importance of mangrove forests with the ecosystem services they provide has become known and appreciated. Various assistance funds from local and international agencies as much as 100 to 500 USD per hectare have already been allotted for mangrove planting (Primavera and Esteban 2008).

Bantayan Island is an island in the province of Cebu that is famous for its white sand, but they are also known for their scallops and the production of a dried fish which the locals call "danggit." This dried "danggit" (Siganus fuscescens) is a delicacy that the area is known for, and this contributes a lot to their economy. The fish is known to inhabit seagrass beds. The beaches of Bantayan have abundant seagrass meadows which explain the abundance of this fish and shells like scallops. Only a few areas in the island are known to have mangrove forests.

In October 2015, various newspaper reports of locals (Mangubat 2012; Codilla 2015a, b; Quintas 2015) from the island complaining about how some fishermen in the island have been planting propagules of Rhizophora $s p$. mangroves on seagrass beds. It has been reported that around 12 ha of these mangroves have been planted on the seagrass beds of the island as of 2015. The planting began in June 2015 when the national government allotted 1 billion Philippine peso (18 million USD) for mangrove reforestation after the typhoon Haiyan hit the country. The storm surges during the typhoon destroyed mangrove forests and devastated coastal communities like Bantayan Island which is found in the northern part of Cebu. About 89 million Philippine peso (1.7 million USD) was for the planting of mangroves in these northern areas of Cebu.

Table 2 Measures of biodiversity for macroinvertebrates found in the study site

\begin{tabular}{lll}
\hline Measures of macroinvertebrate biodiversity & With mangrove & Without mangrove \\
\hline Species richness & 9 & 7 \\
Dominance $(D)$ & 0.290 & 0.184 \\
Simpson's index $\left(D_{s}\right)$ & 0.710 & 0.816 \\
Shannon-Wiener index of diversity $(H)$ & 1.566 & 1.810 \\
Evenness index & 0.532 & 0.873 \\
Jaccard coefficient $\left(S_{J}\right)$ & 0.143 & \\
\hline
\end{tabular}

Shannon-Wiener index $p=0.2770$; Simpson's index $p=0.1399$ 

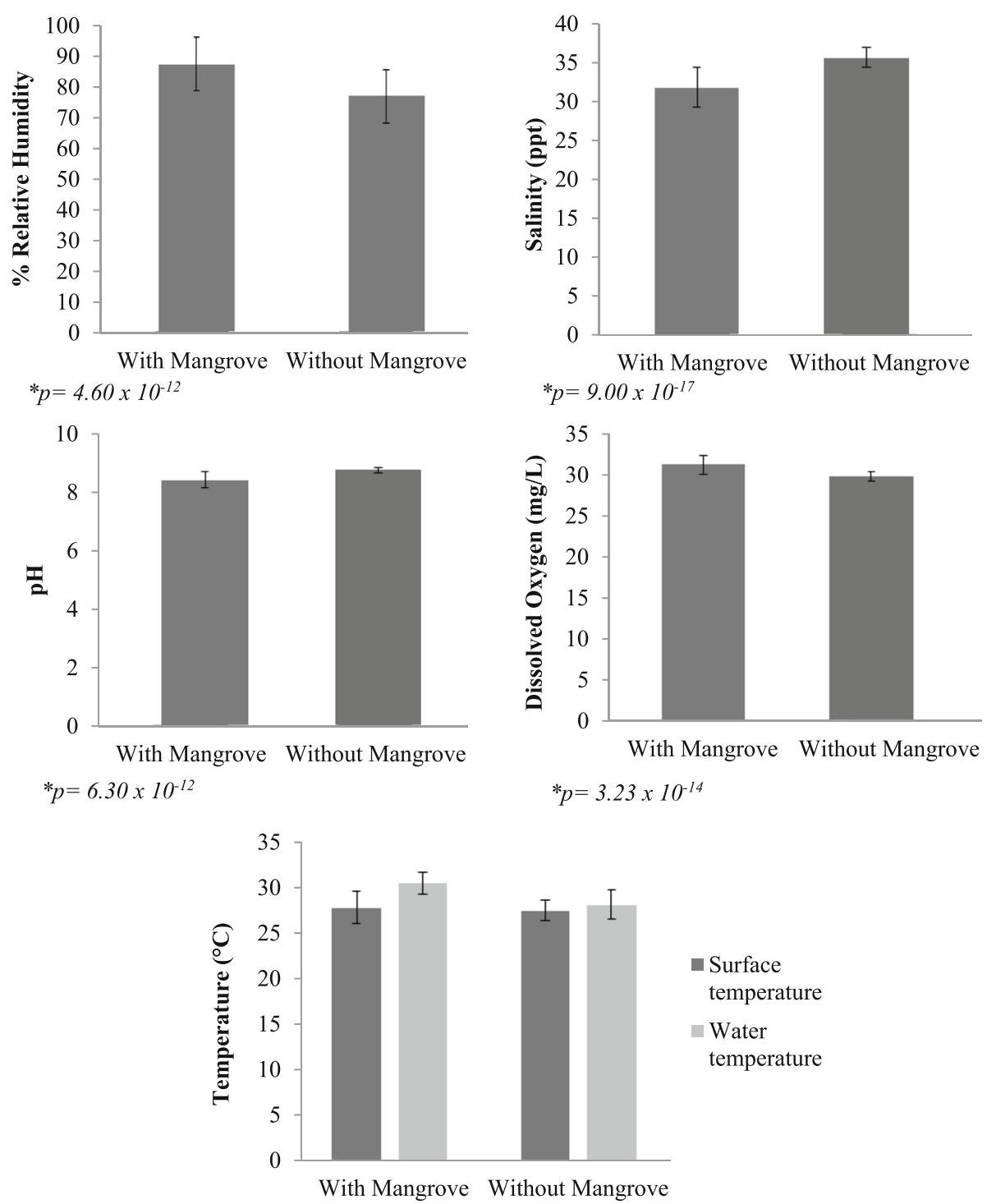

$$
\begin{gathered}
*_{p}=0.30(\text { surface temp }) \\
*^{*} p=4.21 \times 10^{-14}(\text { water temp })
\end{gathered}
$$

Fig. 4 The various physico-chemical parameters gathered from the study site

The local complaints mainly came from people who had businesses related to shellfish gleaning and "danggit." They complained that the planting of the mangroves has decreased their catch of "danggit" and they were afraid that further alteration of the seagrass beds would affect their economy as well as environment. It turns out that for every propagule planted, each fisherman is given 2 Philippines peso (0.04 USD) and that the money might be one of the reasons why these fishermen have been planting mangrove propagules on the seagrass beds (Mangubat 2012; Codilla 2015a, b; Quintas 2015). As of October 2015, it has been reported that the government has been sending out initiatives to properly monitor the mangrove planting done by the fishermen.

It has been observed in the Philippines that there is a prevalent tendency for atypical habitat of mangroves, such as seagrass beds, to be the chosen location for mangrove plantation (Samson and Rollon 2008). This practice often uses exclusively the genus Rhizophora which leads to creating a monospecific Rhizophora mangrove forest. It is important to note that various substrates, salinity and flooding tolerance together with mangrove natural zonation, are considered for every mangrove species adaptation. The lateral roots of Sonneratia and Avicennia that firmly anchor the tree below 
ground allow them to dominate in the open seafront while the prop roots of Rhizophora species which cannot withstand the strong wave power is usually found mid-forest. Therefore, planting of Rhizophora from landward to seaward and most especially on seagrass beds is a common practice of placing the wrong species in the wrong sites.

Sixty 60 species of seagrasses are described worldwide ${ }^{6}$ and 18 species are found in the Philippines (Fortes 2004). Reflected in Table 1 are the 6 seagrass species, namely Cymodocea sp., Thalassia sp., Halodule sp., Enhalus sp., Halophila sp., Syringodium sp., found in the site without mangroves (Barangay Ocoy) while the site with mangroves (Barangay Marikaban) only had 4 species. The species composition per study site must have varied most likely due to the physical characteristics of the study areas, especially the substratum which is a very important regulator of seagrass distribution (Greve and Binzer 2004). Both Halophila sp. and Syringodium sp., which are the species not found in the site with mangroves, prefer sandy substrates (Calumpong and Menez 1994; Meode et al. 2014). Based on observation, the site with Rhizophora had a muddy substrate that is suited for the seagrass species occurring in the area. Most mangroves thrive more on muddy substrates where there is a supply of muddy sediment (Bird 2005). Enhalus and Thalassia form a major association in muddy substrates (Calumpong and Menez 1994); this was also observed in the area. Thalassia $s p$. is the most ecologically important plant on the submerged mangrove bottom as it stabilizes the mud and offers substrate, food, and shelter to animals (Rutzler and Feller 1988).

Although there is no statistically significant difference on mean percent seagrass substrate cover between the sites with and without mangrove plantation (Fig. 3), it is still evident that the area without mangroves had a higher seagrass substrate cover. This less pronounced effect is likely because the mangroves are still saplings and aboveground competition is not yet high. Presence of seagrass may still be observed in the area planted with mangrove because they are not yet under the closed canopy that may eventually reduce photosynthetically active radiation and competition for growing space (Sharma et al. 2017; Ellison et al. 1996; Simpson et al. 2013). Although only percent cover of seagrass substrates was acquired regardless of diversity indices and species composition, this study provides additional baseline data on the impact of mangrove planting in Bantayan seagrass beds.

Mangroves provide additional coastal protection; however, this planting practice of the country may lead to the alteration of seagrass ecosystems. This could change the community structure and dynamics of the seagrass ecosystem (Primavera and Esteban 2008; Orth et al. 2006).
One of the communities associated with seagrasses is the macroinvertebrate fauna. Determining their communities in the two conditions of seagrass ecosystems (with or without mangrove plantation) was investigated in this study. It was observed that seagrass beds planted with mangroves had lesser values for Shannon-Wiener and Simpson's index of diversity compared to seagrass beds without the planted mangroves (Table 2). This result is similar to a study done by Leung (2015) wherein macrobenthic communities decreased with the increase of artificial mangrove habitats. It implies that there should be proper species and site selection before mangrove planting. The decrease in macroinvertebrate diversity could also be attributed to the increased sedimentation by the mangroves. The increase in sediments may have invited new dominant invertebrates in the area that use the sediments to hide from predators. Invertebrates like crabs dig and burrow in these sediments and use mangroves as nurseries of their young (Demopoulos and Smith 2010; Kristensen 2008). This explains the low Jaccard similarity index between the two sites as more crabs were seen in the area with mangroves. The results imply that there was difference in the macroinvertebrate community structure. It was observed that between both study sites, coral species were closer to the seagrass bed without mangroves. The presence of coral species in Barangay Ocoy could be associated to having an average value of water temperature that was more optimum and favorable for coral growth in the area without mangroves. This indicates that the area void of mangroves was able to support the existence of corals because water temperature falls within the range of $25-29^{\circ} \mathrm{C}$ which is the most optimum temperature for coral growth (Vine 1986). Severe mortality of corals may occur if there are dramatic variations of temperature from the optimum value (Brown 2000).

Planting of monospecific Rhizophora sp. in non-mangrove areas should be discouraged. Gaining benefit for one ecosystem at the expense of another valuable ecosystem is not ecologically ideal. Negative consequences are expected when seagrass beds are replaced by mangrove plantations because of the various ecological services it offers to the adjacent coastal environment (Wright and Jones 2006; Fourqurean et al. 2012). Therefore, mangroves should be planted in their original habitat that has been converted to brackish-water aquaculture ponds (Samson and Rollon 2008; Ellison et al. 1996).

\section{Conclusion}

In the Philippines, mangrove planting has been encouraged as the mangrove ecosystem in the country has been devastated by natural calamity (typhoon) and anthropogenic activities. In the process, other coastal ecosystems 
such as seagrass ecosystems have been planted on with mangroves. This study compared area with intact seagrass ecosystems (Barangay Ocoy) with those that have been planted on with mangroves (Barangay Marikaban) in Santa Fe, Bantayan. Findings showed that there was not yet much significant difference between the two areas assessed. The changes between the two areas may not be so profound yet since the mangroves were still saplings (planting done in 2015). However, it was observed that the seagrass cover and macroinvertebrates in Barangay Marikaban was lesser. The Jaccard coefficient of similarity between the two communities was low (0.14) implying that the seagrass community in Barangay Marikaban has begun to alter. We recommend proper monitoring of future mangrove planting activities and that this activity should not disrupt another ecosystem as all ecosystems are important.

\section{Acknowledgements}

We are greatly thankful to Mr. Sirrus Jade Quijote and Ms. Jisa Rica Quijote for assisting us in the collection of data. We are also thankful to Mr. Francis Dave de Asis for his help in the analysis of data. Special thanks to the barangay captain of Bantayan, Adory Pleños, for accommodating us and allowing us to conduct our study in the island. To our teacher, Dr. Richard Parilla, we are grateful for his guidance.

\section{Funding}

Not applicable.

\section{Availability of data and materials}

The datasets generated and analyzed during the current study are not publicly available because all were collected primarily by the authors themselves but are available from the corresponding author on reasonable request.

\section{Authors' contributions}

ARM, JMP, and JYD were major contributors in the conception, acquisition of data, analysis and interpretation of data, and writing of the manuscript. All authors read and approved the final manuscript.

\section{Ethics approval and consent to participate}

Not applicable.

\section{Consent for publication}

Not applicable.

\section{Competing interests}

The authors declare that they have no competing interests.

\section{Publisher's Note}

Springer Nature remains neutral with regard to jurisdictional claims in published maps and institutional affiliations.

Received: 5 February 2019 Accepted: 1 April 2019

Published online: 13 May 2019

\section{References}

Bird E. Mangroves, geomorphology. In: Schwartz M, editor. Encyclopedia of coastal science. Encyclopedia of earth science series: Springer; 2005. https:// doi.org/10.1007/1-4020-3880-1

Brander LM, Hussain SS, McVittie A, Verburg PH, de Groot RS, van der Ploeg S. Ecosystem service values for mangroves in Southeast Asia: a meta-analysis and value transfer application. Ecosyst Serv. 2012;1:62-9.

Brown B. The significance of pollution in eliciting the 'bleaching' response in symbiotic cnidarians. Int J Environ Pollut. 2000;13:392-415.
Bureau of Fisheries and Aquatic Management VII. Participatory Coastal Resource Assessment of Santa Fe, Cebu. Cebu: Bureau of Fisheries and Aquatic Management VII; 2009.

Calumpong H, Menez E. Seagrass beds of the Philippines. Ann Trop Res. 1994;16:1-15.

Codilla MZ. DENR told to stop planting mangroves in seagrass beds: Cebu Daily News; 2015a. https://cebudailynews.inquirer.net/68698/denr-told-to-stopplanting-mangroves-in-seagrass-beds?utm_expid=. XqNwTug2W6nwDVUSgFJXed.1. Accessed 19 Oct 2018

Codilla MZ. Bakhaw' deprives seagrass fauna of their habitat: Cebu Daily News; 2015b. https://cebudailynews.inquirer.net/70107/bakhaw-deprives-seagrassfauna-of-their-habitat?utm_expid=.XgNwTug2W6nwDVUSgFJXed.1. Accessed 19 Oct 2018

Demopoulos AW, Smith CR. Invasive mangroves alter macrofaunal community structure and facilitate opportunistic exotics. Mar Ecol Prog Ser. 2010;404:51-67.

Ellison A, Farnsworth E, Twilley R. Facultative mutualism between red mangroves and root-fouling sponges in Belizean mangal. Ecology. 1996;77:2431-44. https://doi.org/10.2307/2265744.

Fortes M. Wetland conservation and management in the Philippines. In: Wetlands ecosystems in Asia: function and management. Oxford: Elsevier; 2004. p. 233-62.

Fourqurean J, Duarte C, Kennedy H, Marba N, Holmer M, Mateo M, et al. Seagrass ecosystems as a globally significant carbon stock. Nat Geosci. 2012:5:505-9.

Greve T, Binzer T. Which factors regulate seagrass growth and distribution? In: European seagrasses: an introduction to monitoring and management. The monitoring and management of European beds project; 2004. p. 19-23.

Jackson EL, Rowden AA, Atrill MJ, Jones M. The importance of seagrass beds as a habitat for fishery species. Oceanogr Mar Biol. 2001;39:269-304.

Kristensen E. Mangrove crabs as ecosystem engineers; with emphasis on sediment processes. J Sea Res. 2008:59:30-43.

Leung JY. Habitat heterogeneity affects ecological functions of macrobenthic communities in a mangrove: implication for the impact of restoration and afforestation. Glob Ecol Conserv. 2015;4:423-33.

Mangubat EG. Will 'bakhaw' project spoil Bantayan seagrass beds?. Cebu daily News; 2012. https://cebudailynews.inquirer.net/69477/will-bakhaw-projectspoil-bantayan-seagrass-beds?utm_expid=.XgNwTug2W6nwDVUSgFJXed.1. Accessed 19 Oct 2018.

McKenzie L, Campbell S, Roder C. Seagrass-watch: manual for mapping and monitoring seagrass resources by community (citizen) volunteers. 2003. http://www.seagrasswatch.org/Methods/Manuals/SeagrassWatch monitoring_guidelines_2ndEdition.pdf. Accessed 6 Oct 2018.

Meode M, Montes E, Paloma A, Panal M, Pesquera N. Distribution and abundance of seagrasses of Bontoc, Southern Leyte. JESTEC. 2014;2:93-103.

Orth RJ, Carruthers TJB, Dennison WC, Duarte CM, Fourqurean JW, Heck KL, Hughes AR, Kendrick GA, Kenworthy WJ, Olyarnik S, Short FT, Waycott M, Williams SL. A global crisis for seagrass ecosystems. BioScience. 2006:56:987-96.

Park YS, Lek S, Baehr C, Jørgensen SE. Advanced modelling techniques studying global changes in environmental sciences, vol. 27. 1st ed. Oxford: Elsevier; 2015. p. 27.

Primavera JH, Esteban JMA. A review of mangrove rehabilitation in the Philippines: successes, failures and future prospects. Wetl Ecol Manag. 2008, 16:345. https://doi.org/10.1007/s11273-008-9101-y.

Quintas KB. Stakeholders fail to solve mangrove planting issues: Philstar; 2015. https://www.philstar.com/cebu-news/2015/10/06/1508102/stakeholders-failsolve-mangrove-planting-issues. Accessed 19 Oct 2018.

Roozbahani MM, Nabavi SMB, Farshchi P, Rasekh A. Studies on the benthic macroinvertebrates diversity species as bio-indicators of environmental health in Bahrekan Bay (Northwest of Persian Gulf). Afr J Biotechnol. 2010;9:27.

Rutzler K, Feller C. Mangrove swamp communities. Oceanus. 1988:40:17-24.

Samson M, Rollon R. Growth performance of planted mangroves in the Philippines: revisiting forest management strategies. Ambio. 2008:37:234-40.

Sharma S, Nadaoka K, Nakaoka M, Uy W, MacKenzie R, Friess D, Fortes M. Growth performance and structure of a mangrove afforestation project on a former seagrass bed, Mindanao Island, Philippines. Hydrobiologia. 2017:803:359-71. https://doi.org/10.1007/s10750-017-3252-x.

Simpson L, Feller I, Chapman S. Effects of competition and nutrient enrichment on Avicennia germinans in the salt marsh-mangrove ecotone. Aquat Bot. 2013;104:55-9. https://doi.org/10.1016/.aquabot.2012.09.006

Vine P. Red Sea invertebrates. London: Immel Publishing; 1986.

Wright J, Jones C. The concept of organisms as ecosystem engineers ten years on: progress, limitations, and challenges. BioScience. 2006;56:203-9. 